\title{
Assessing the Potential of the Water Soluble Allelopaths of Marsilea minuta IN RICE AND WHEAT ${ }^{1}$
}

\author{
Avaliação do Potencial de Compostos Alelopáticos Hidrossolúveis de Marsilea minuta em Arroz \\ e Trigo
}

\author{
TANVEER, A. ${ }^{2}$, SAFDAR, M.E. ${ }^{3}$, SULEMAN, M. $^{2}$, TAHIR, M. ${ }^{2}$, ZAMIR, S.I. ${ }^{2}$, and NADEEM, M.A. ${ }^{2}$
}

\begin{abstract}
To investigate the allelopathic effect of Marsilea minuta against the germination and seedling growths of rice (Oryza sativa) and wheat (Triticum aestivum), germination bioassays were conducted in both Petri dish and soil cultures in laboratory conditions. Rice and wheat seeds were allowed to germinate in a $1,2,3,4$, and $5 \%(\mathrm{w} / \mathrm{v})$ aqueous extract of whole plant and $2,4,6$, and $8 \%(\mathrm{w} / \mathrm{w})$ plant residue-incorporated soils of M. minuta. In Petri dish experiments, $5 \%(\mathrm{w} / \mathrm{v})$ an aqueous extract of $M$. mimuta showed significantly lower germination percentages $(18.8 \%$ and $56.3 \%)$, root lengths $(0.9$ and $4.5 \mathrm{~cm})$, shoot lengths $(3.3$ and $12.4 \mathrm{~cm})$, seedling lengths $(4.1$ and $25.0 \mathrm{~cm})$, root dry weights $(1.4$ and $5.6 \mathrm{~g})$, shoot dry weights $(1.1$ and $9.0 \mathrm{~g}$ ), seedling biomasses (2.5 and $14.6 \mathrm{~g}$ ), and seedling vigor indices (77.4 and 957.3) in rice and wheat, respectively. In pot experiments, the $M$. minuta residue infested soil, with $8 \%$ concentration, produced significantly lower germination percentages (25.3 and $37.5 \%)$, root lengths $(2.7$ and $6.1 \mathrm{~cm})$, shoot lengths $(6.2$ and $16.5 \mathrm{~cm})$, seedling lengths $(8.9$ and $22.6 \mathrm{~cm})$, root dry weights $(2.4$ and $5.5 \mathrm{~g})$, shoot dry weights $(4.0$ and $2.8 \mathrm{~g})$, seedling biomasses (6.4 and $8.3 \mathrm{~g}$ ), and seedling vigor indices (224.1 and 855.3) in rice and wheat, respectively. The highest phytotoxic action of $5 \%$ aqueous whole plant extract of $M$. minuta against test crops seem to be due to the presence of two potent phenolic compounds, namely $p$-coumaric acid $\left(2.91 \mathrm{mg} \mathrm{L}^{-1}\right)$ and $m$-coumaric acid $\left(1.59 \mathrm{mg} \mathrm{L}^{-1}\right)$ as determined by HPLC analysis.
\end{abstract}

Keywords: allelopathy, dwarf water clover, Oryza sativa, plant bioassay, soil bioassay, Triticum aestivum.

\begin{abstract}
RESUMO - Com o objetivo de investigar o efeito alelopático de Marsilea minuta sobre a germinação e crescimento de plântulas de arroz (Oryza sativa) e trigo (Triticum aestivum), bioensaios foram realizados tanto em placas de Petri como em solo, em condições de laboratório. Sementes de arroz e trigo foram germinadas em 1, 2, 3, 4 e 5\% (m/v) de extrato aquoso de planta inteira e 2, 4, 6 e 8\% $(\mathrm{m} / \mathrm{m})$ de residuos de $\boldsymbol{M}$. minuta incorporados ao solo. Em placas de Petri, $5 \%(\mathrm{~m} / \mathrm{v})$ de extrato aquoso de $\boldsymbol{M}$. minuta resultou em menores porcentagens de germinação (18,8 e 56,3\%), comprimento de raiz (0,9 e 4,5 cm), comprimento da parte aérea $(3,3$ e 12,4 cm) e de plântulas $(4,1$ e 25,0 cm), massa seca das raizes (1,4 e 5,6 g) e de parte aérea (1,1 e 9,0 g), biomassa (2,5 e 14,6 g) e indice de vigor das plântulas $(77,4$ e 957,3) em arroz e trigo, respectivamente. Em experimentos em vasos, a incorporação ao solo de $\boldsymbol{M}$. minuta a $8 \%$ reduziu a germinação (25,3 e 37,5\%), os comprimentos de raiz $(2,7$ e 6,1 cm), parte aérea $(6,2$ e 16,5 cm) e plântulas $(8,9$ e 22,6 cm), a massa seca de raiz $(2,4$ e 5,5 g), parte aérea $(4,0$ e 2,8 g) e plântulas $(6,4$ e 8,3 g) e os indices de vigor das plântulas $(224,1$ e 855,3) de arroz e trigo, respectivamente. O maior efeito fitotóxico de extrato aquoso de $\boldsymbol{M}$. minuta a $5 \%$ sobre as culturas deve-se à presença de dois compostos fenólicos potentes: ácidos p cumárico (2,91 $\left.\mathrm{mg} \mathrm{L}^{-1}\right)$ e m cumárico (1,59 mg $\left.\mathrm{L}^{-1}\right)$, conforme determinação por HPLC.
\end{abstract}

Palavras-chave: alelopatia, trevo-de-água-anão, Oryza sativa, bioensaio vegetal, bioensaio em solo, Triticum aestivum.

1 Recebido para publicação em 2.4.2014 e aprovado em 16.7.2014.

2 University of Agriculture, Faisalabad, 38040, Pakistan, <drasiftanveeruaf@hotmail.com>; ${ }^{3}$ University College of Agriculture, University of Sargodha, Sargodha, Pakistan. 


\section{INTRODUCTION}

Weeds interfere with human activities in cropped and non-cropped areas. In addition to competing crops for common growth factors, allelopathy is the main weapon used by weeds which cause reduction in their growth and yield (Zimdahl, 2007). Allelopathy is the deleterious interaction between two organisms or cell types that are allogeneic to each other. It is used by plants as a weapon to prevent other plants from growing too closely (Kim \& Shin, 1998). Allelochemicals are secondary metabolites that are synthesized by almost all plants but are not required for their metabolism i.e. growth, development, and reproduction of the allelopathic organism (Stanp, 2003). The possible role of these toxic substances within plants may be their negative allelopathic effects against herbivory, an important plant defense system.

Phytotoxic inhibitory action at a higher concentration and neutral or sometimes promotive action at a lower concentration against targeted species is a common feature of most allelochemicals (Chung \& Miller, 1995). Various plant organs, including leaves, fruits, flowers, roots, stem, rhizomes, and seeds, have chemicals with allelopathic potential (Tinnin \& Muller, 1972). These substances, i.e. terpenoids, phenolics, alkaloids, fatty acids, steroids, and acetylene, are called allelochemicals (Kohli et al., 1997). Due to the action of allelochemicals, a large number of biochemical reactions and physiological functions are affected, such as seed germination, cell division, cell elongation, membrane permeability, and ion uptake (Setia et al., 2007). However, the detrimental effects of allelochemicals are more pronounced on seed germination and seedling growth (Bogatek et al., 2006).

There are 1,800 species reported as weeds of rice that exhibit variability in germination (Rao et al., 2007). Marsilea minuta, which belongs to the family Marsileaceae, is commonly known as dwarf water clover or fourleaf clover because the long-stalked leaves have four clover-like leaflets and are either held above water or submerged. $M$. minuta is a perennial fern with slender, rooted, creeping, and branching rhizomes bearing erect leaves along their length. It is found in shallow pools, at the edges of rivers, swamps, ditches, and in lowland rice fields (CABI, 2013). Considerable yield losses in rice with $M$. minuta have been observed (Rabbani et al., 2011). Although the allelopathic effect of various weeds on rice and wheat has been documented (Singh et al., 2005; Samad et al., 2008; Jalageria et al., 2010), no research has been conducted yet on the allelopathic effects of $M$. minuta on rice and wheat crops. Studies were, therefore, planned to assess the allelopathic effects of aqueous extracts and $M$. minuta residue infested soil with different concentrations on seed germination and seedling growth of rice and wheat.

\section{MATERIAL AND METHODS}

Preparation of aqueous extracts and residue infested soil: Plants of Marsilea minuta were uprooted at maturity from the Agronomic Research Area, University of Agriculture, Faisalabad, Pakistan and were dried under shade. The dried intact plants were put in distilled water with 1:20 (weight/volume) ratio for 24 hours at room temperature (Hussain $\&$ Gadoon, 1981). An aqueous extract was obtained by filtering through 10 and 60 mesh sieves and then through Minisart nonpyrogenic, $0.45 \mu \mathrm{m}$ filters. The $5 \%$ aqueous extract of whole plant of $M$. minuta was diluted with distilled water to prepare its $1,2,3$, and $4 \%$ concentrations.

For preparing the $M$. minuta residue infested soil, dried intact plants of $M$. minuta were chopped with the help of scissors and ground with the help of a grinder. These were mixed with soil that was collected from a weed free site at the Agronomy Research Area, University of Agriculture, Faisalabad, Pakistan in $1: 50,1: 25,1: 16.7$, and $1: 12.5$ (weight/weight) ratios to get 2, 4, 6, and $8 \%$ $M$. minuta residue infested soil. For making a homogeneous mixture, $M$. minuta residue infested soil samples were allowed to decompose for 15 days at room temperature.

Determination of suspected phenolics: For the identification and quantification of their suspected phytotoxins, aqueous extracts were chemically analyzed on Shimadzu HPLC system (Model SCL-10A, Tokyo, Japan). 
The peaks were detected by a UV detector. Standards of suspected phytotoxins (Aldrich, St Louis, USA) were run similarly for their identification and quantification. Concentration of each isolated compound was determined by the following equation:

$$
\text { Concentration }(\mathrm{ppm})=\frac{\text { Area of the sample }}{\text { Area of the standard }} \times \text { Concentration of the standard } \times \text { Dilution factor }
$$

Phytotoxic composition of an aqueous extract with $5 \%$ (weight/volume) concentration of M. minuta was presented in Table 1.

Table 1 - Phenolic composition (mg L $\left.\mathrm{L}^{-1}\right)$ of aqueous extract of M. minuta

\begin{tabular}{|r|l|c|}
\hline $\begin{array}{r}\text { Sr. } \\
\text { No. }\end{array}$ & \multicolumn{1}{|c|}{ Phenolics } & $\begin{array}{c}\text { Concentration } \\
\left(\mathrm{mg} \mathrm{L}^{-1}\right)\end{array}$ \\
\hline 1 & gallic acid & - \\
\hline 2 & caffeic acid & - \\
\hline 3 & 4-hydroxy-3-methoxy benzoic acid & - \\
\hline 4 & p-coumaric acid & 2.91 \\
\hline 5 & m-coumaric acid & 1.59 \\
\hline 6 & chromatotropic acid & - \\
\hline 7 & vanillic acid & - \\
\hline 8 & syringic acid & - \\
\hline 9 & ferulic acid & - \\
\hline 10 & chlorogenic acid & - \\
\hline
\end{tabular}

Experimental material and growth conditions: two sets of experiments were executed in laboratory conditions at Weed Science Laboratory, Department of Agronomy, University of Agriculture, Faisalabad, Pakistan during 2012. For Petri plate based plant bioassay, 20 seeds of rice and wheat were placed in a $9 \mathrm{~cm}$ diameter filter paper-lined Petri dish. At the beginning of the experiment, $8 \mathrm{~mL}$ of aqueous extract of each of the 1, 2, 3, 4 , and 5\% (weight/volume) concentrations was added in every Petri dish separately, whereas in control treatment the same volume of distilled water was poured.

For pot based soil bioassay, 10 seeds of rice and wheat were sown at equal distance and depth in plastic pots of $11-\mathrm{cm}$ diameter and $5 \mathrm{~cm}$ depth each filled with the $200 \mathrm{~g}$ of homogeneous $M$. minuta residue infested soil having 2, 4, 6, and 8\% (weight/weight) concentrations. Pots filled with same quantity of soil with no weed residues were kept as the control treatment. Experimental Petri plates and pots were kept on the laboratory shelves and 24 hours minimum and maximum temperatures were recorded. Minimum and maximum temperatures for plant and soil bioassay experiments of rice were $31^{\circ} \mathrm{C}$ and $38{ }^{\circ} \mathrm{C}$, whereas those of wheat were $20^{\circ} \mathrm{C}$ and $28^{\circ} \mathrm{C}$ throughout the course of each experiment. Each treatment in plant and soil bioassay experiments was replicated four times and experiments were laid out in completely randomized design (CRD).

Data collection and analysis: the daily germination count data of both rice and wheat were recorded for a period of 16 days. These data were used to calculate the germination percentage. At the final germination count, seedlings were measured for their root and shoot lengths. Roots and shoots were separated and their dry weights were taken after drying them in an electrical oven at $65^{\circ} \mathrm{C}$ for $48 \mathrm{hrs}$. Germination percentage and seedling length were used to calculate the seedling vigor index (SVI) by the following formula as described by Orchard (1977):

$$
\begin{aligned}
\mathrm{SVI}= & {[\text { seedling length }(\mathrm{cm}) \times \text { germination }} \\
& \text { percentage }] .
\end{aligned}
$$

Fischer's analysis of the variance technique was used to statistically analyze the data and the Least Significant Difference test at a 5\% probability level was used to compare treatment means (Steel et al., 1999).

\section{RESULTS AND DISCUSSION}

The mean squares of germination percentage and various seedling vigor parameters of rice and wheat as influenced by aqueous extracts and $M$. minuta residue infested soil with varied concentrations are shown in Tables 2 and 3, respectively. The comparison of mean squares shows that germination percentages, shoot lengths, root 

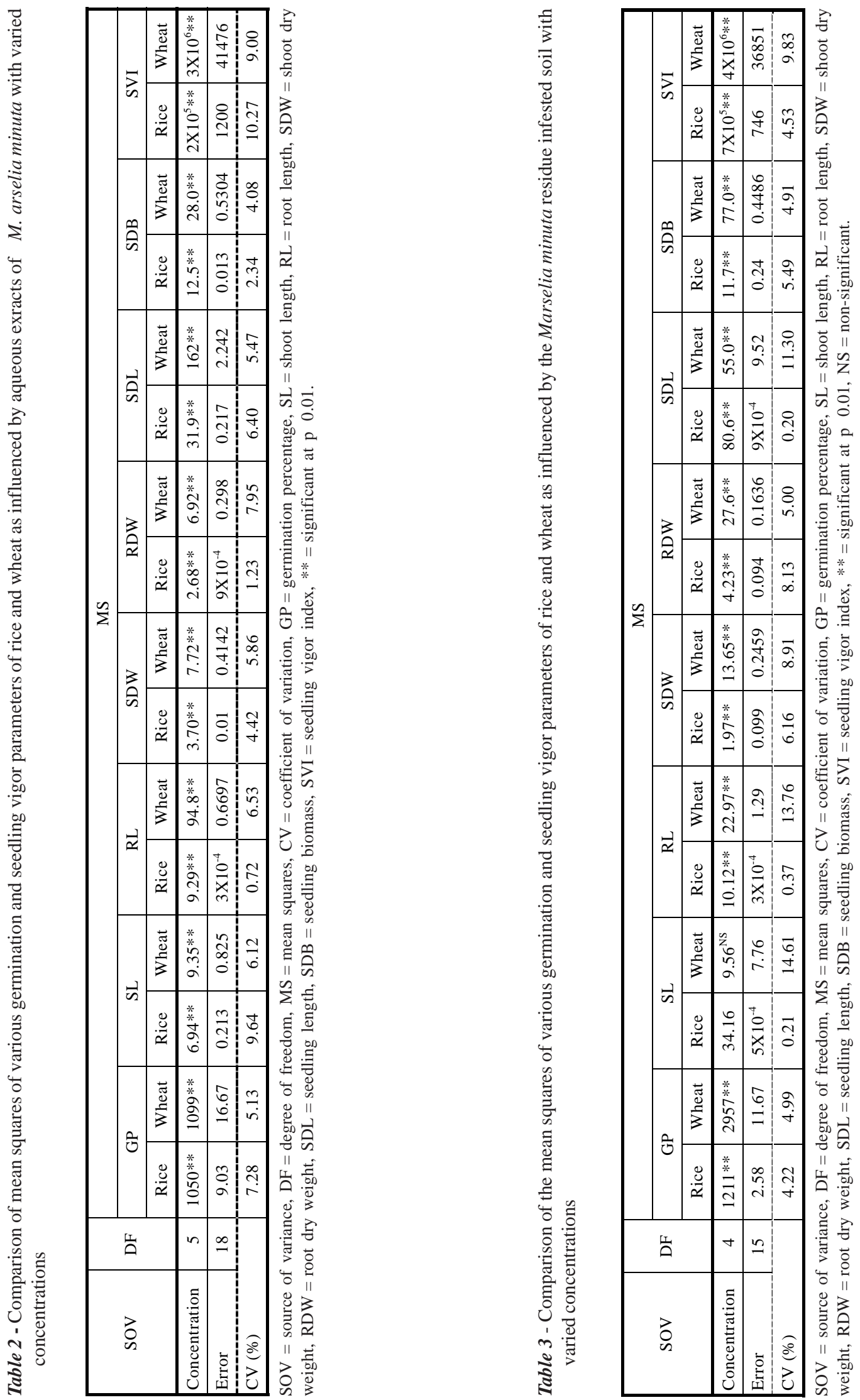
lengths, shoot dry weights, root dry weights, seedling lengths, seedling biomasses, and seedling vigor indices of both crops were significantly $(\mathrm{p} \leq 0.01)$ affected by aqueous extracts as well as $M$. minuta residue infested soil. However, the shoot length of wheat was not significantly influenced by the M. minuta residue infested soil. Germination percentage, root and shoot lengths of rice and wheat at various concentrations of aqueous extracts, and $M$. minuta residue infested soil are shown in Figure 1, which indicated that the values of these parameters gradually reduced as the concentrations increased. Statistically significantly lower germination percentages of rice (18.8\% and $25.3 \%$ ) and wheat $(56.3 \%$ and $37.5 \%)$ were noted at the $5 \%(\mathrm{w} / \mathrm{v})$ and $8 \%(\mathrm{w} / \mathrm{w})$ concentrations of aqueous extract and soil incorporate of this weed, respectively.

Regarding the root and shoot lengths, the same concentrations of the aqueous extract of $M$. minuta also produced the significantly least root lengths $(0.88$ and $4.53 \mathrm{~cm})$ and shoot lengths (3.25 and $12.43 \mathrm{~cm}$ ) in rice and wheat, respectively. Rice and wheat seedlings emerged out of the $M$. minuta residue infested soil with $8 \%$ concentration produced significantly shorter root lengths (2.7 and $6.1 \mathrm{~cm})$, respectively. Although, among the various $M$. minuta residues infested soil concentrations, a significantly lower shoot length $(6.2 \mathrm{~cm})$ was recorded in rice at this $8 \%$ concentration, non-significant differences were observed in the wheat. Previous allelopathic studies also revealed the phytotoxic inhibitory action of the aqueous extracts of various weeds against the germination and seedling growth of rice and wheat. The root extract of Lantana camara and Achyranthes aspera and the root nodule extract of Cyperus rotundus showed decreased germination percentage and growth in paddy seedlings (Sharma \& Satsangi, 2005). Significant reductions in seedling emergence, root length, and seedling vigor index in rice and wheat with application of $5 \%$ aqueous extracts of root, stem and leaf tissues of Lantana camara and Euphorbia helioscopia, respectively have also been reported by Oudhia \& Tripathi (1999) and Tanveer et al. (2010).
Figure 2 showed root, shoot, and seedling biomasses of rice and wheat as influenced by various concentrations of aqueous extracts and $M$. minuta residue infested soil. The data represent that significantly minimum root dry weights (1.4 g and $6.2 \mathrm{~g})$, shoot dry weights (1.1 g and $10.1 \mathrm{~g})$, and seedling biomasses $(2.5 \mathrm{~g}$ and $16.3 \mathrm{~g})$ resulted in response to a $5 \%$ aqueous extract of $M$. minuta in rice and wheat, respectively. Similarly, rice and wheat seedlings germinated in $8 \% M$. minuta residue infested soil also accumulated the significantly least dry matter in their roots $(2.4 \mathrm{~g}$ and $5.5 \mathrm{~g})$, shoots $(4.0 \mathrm{~g}$ and $2.8 \mathrm{~g})$ as well as whole seedlings (6.4 g and $8.3 \mathrm{~g}$ ), respectively. Data related to seedling length and seedling vigor index of rice and wheat at various concentrations of aqueous extracts and M. minuta residue infested soil are presented in Figure 3, which showed statistically significant differences among their means. A read-through the data revealed that significantly lower seedling lengths (4.1 and $25.9 \mathrm{~cm}$ ) and seedling vigor indices (77.4 and 957.4) of rice and wheat, respectively, were observed in treatment receiving a 5\% aqueous extract of $M$. minuta weed. The similar pattern was also observed in case of $M$. minuta residue infested soil where maximum inhibitory effect was shown by its $8 \%$ concentration gave significantly minimum seedling lengths (8.9 and $22.6 \mathrm{~cm}$ ) and seedling vigor indices (224.1 and 855.3) in rice and wheat, respectively.

Previous allelopathic studies involving the various weeds residue infested soil also proved to be phytotoxic against the germination and seedling growth of rice and wheat. Abu Romman et al. (2011) observed that aqueous leaf leachates of Euphorbia hierosolymitana showed inhibitory effects on seed germination and seedling growth of wheat under filter paper based Petri plate as well as soil based pot cultures. Gupta \& Narayan (2010) also found that the leaf residues of Parthenium hysterophorus, Cassia obtusifolia and Achyranthes aspera incorporated in soil with varied concentrations showed an inhibition of wheat germination and seedling growth. Similarly, a significant reduction in plant growth and biomass production in sorghum, soybean, and groundnut by incorporating leaf residues of Commelina benghalensis, 

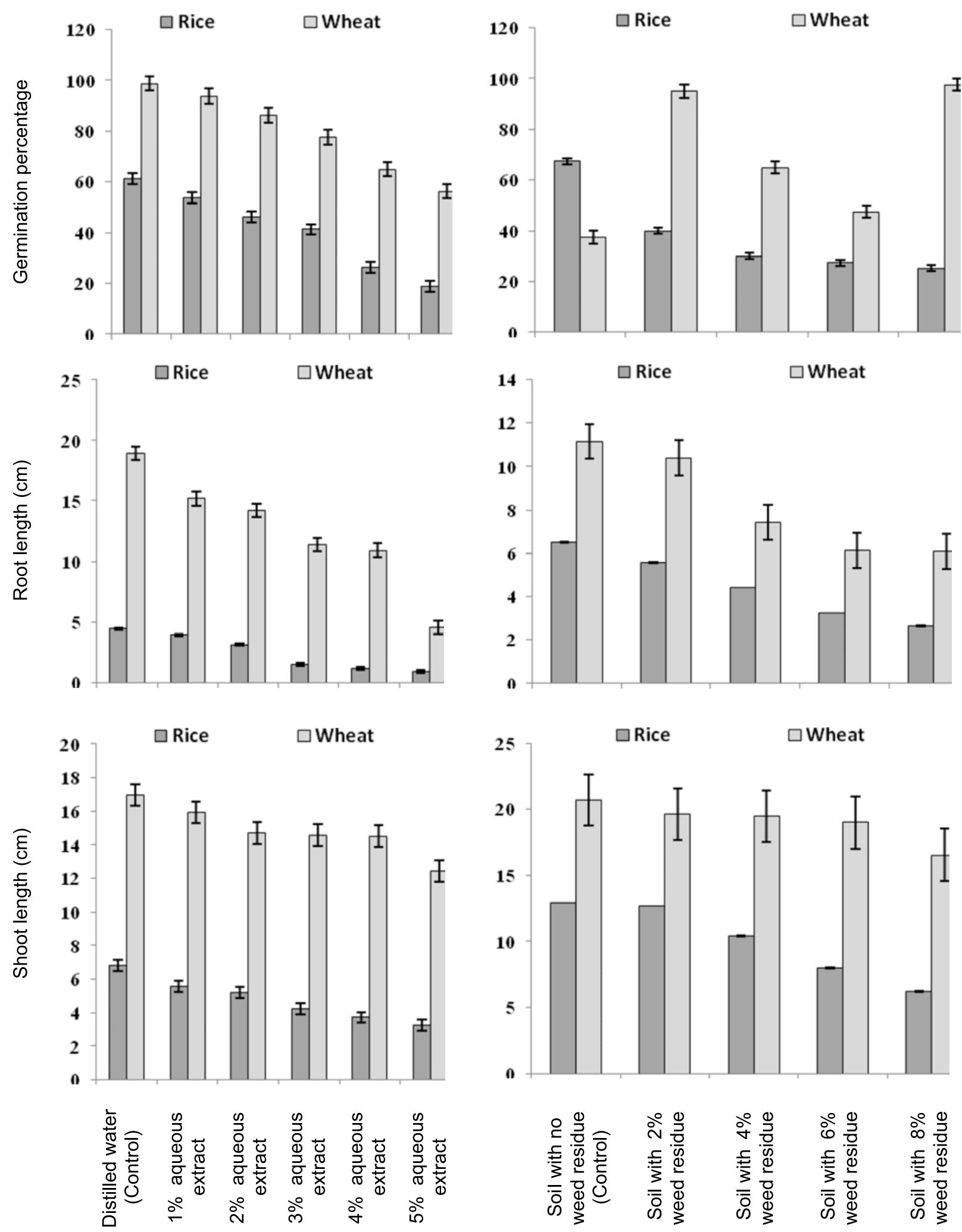

Figure 1 - Germination percentage, root length and shoot length of rice and wheat as influenced by aqueous extracts and $M$. minuta residue infested soil with varied concentrations. 

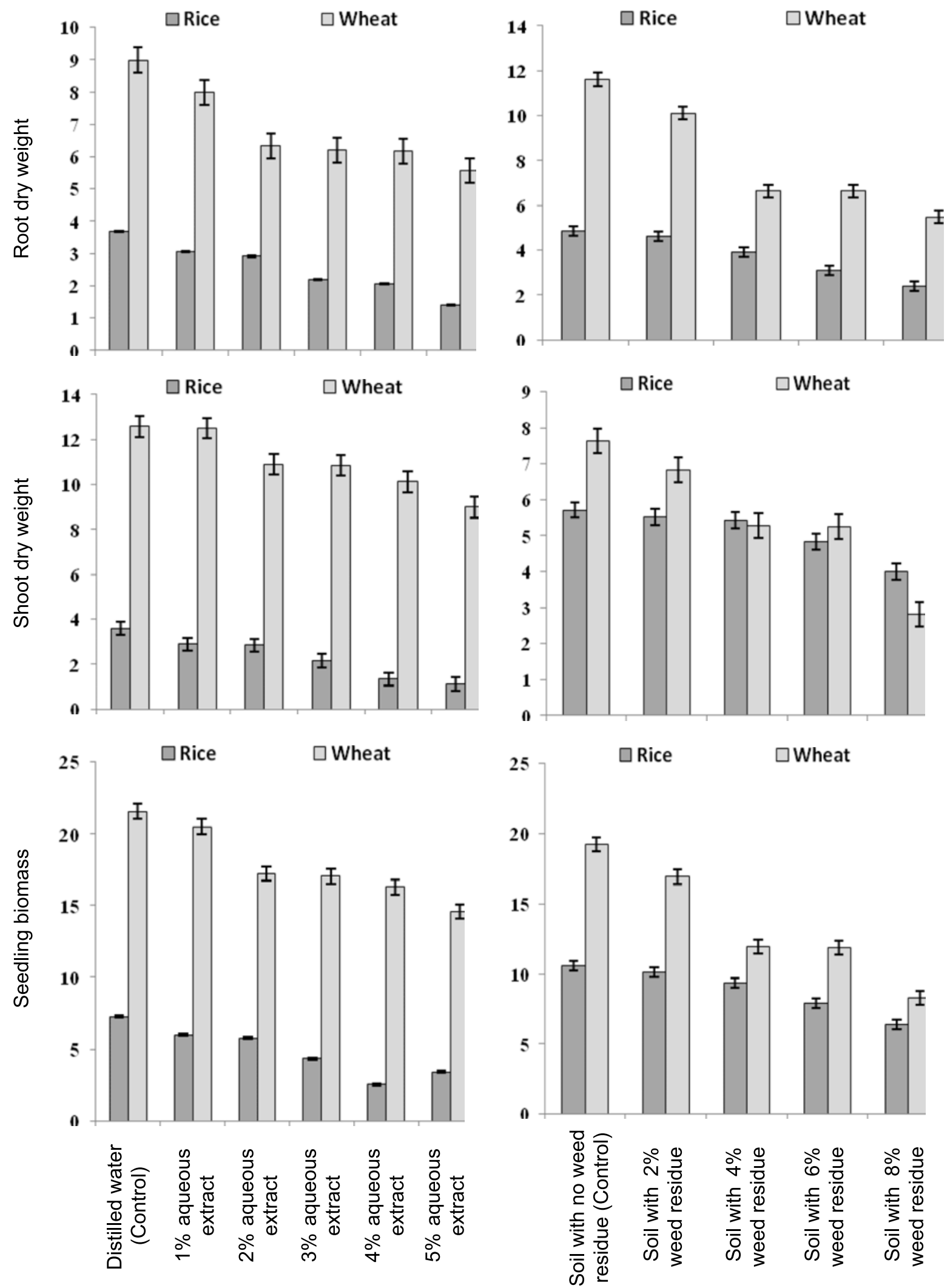

Figure 2 - Root dry weight, shoot dry weight and seedling biomass of rice and wheat as influenced by aqueous extracts and $M$. minuta residue infested soil with varied concentrations. 

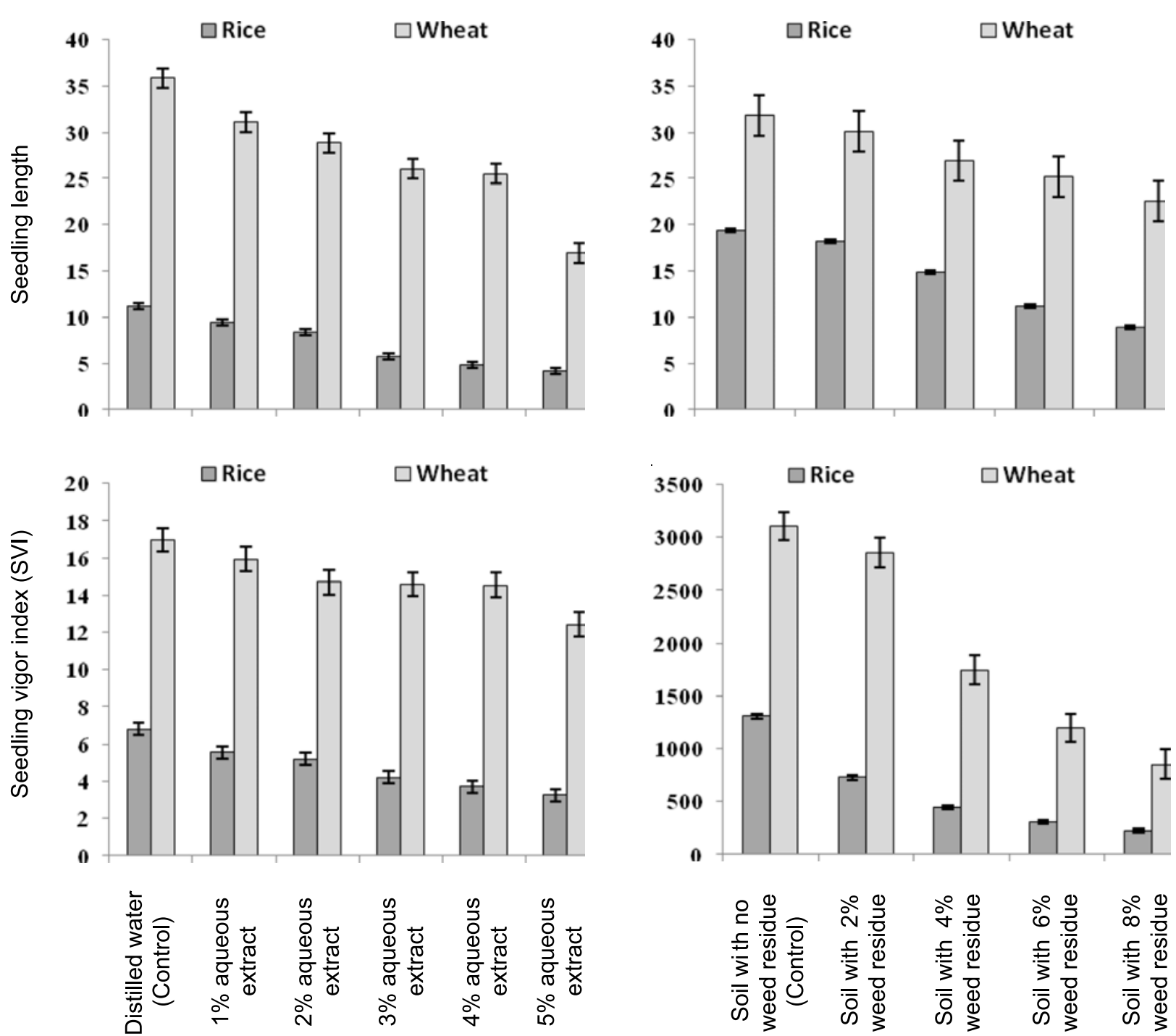

Figure 3 - Seedling length and seedling vigor index (SVI) of rice and wheat as influenced by aqueous extracts and $M$. minuta residue infested soil with varied concentrations.

Cyperus rotundus, Parthenium hysterophorus and Prosopis juliflora leaf in soil, was also observed by Jalageria et al. (2010). Tanveer et al. (2010) also reported significant reductions in seedling emergence, root length, and seedling vigor index of wheat sown in soil collected from Euphorbia helioscopia infested site compared with soil from site free of any vegetation. In our studies, the highest suppressive action of a $5 \%$ aqueous whole plant extract of $M$. minuta against the germination and seedling growth of wheat and rice could be due to the presence of two potent phenolic compounds namely p-coumaric acid (2.91 $\left.\mathrm{mg} \mathrm{L}^{-1}\right)$ and $\mathrm{m}$-coumaric acid (1.59 $\left.\mathrm{mg} \mathrm{L}^{-1}\right)$ as determined by HPLC individual phenolic detection (Table 1).

\section{ACKNOWLEDGMENTS}

Authors of this manuscript greatly acknowledge Dr. Razia Riaz, Research Officer, Hi Tech. Laboratory, University of Agriculture, Faisalabad, Pakistan for his kind cooperation in providing facilities for HPLC studies. 


\section{LITERATURE CITED}

ABU-ROMMAN, S. et al. Allelopathic effects of spurge (Euphorbia hierosolymitana) on wheat (Triticum durum). Am. J. Agric. Environ. Sci., v. 7, n. 3, p. 298-302, 2010.

BOGATEK, R. A. et al. Allelopathic effects of Sunflower extracts on mustard seed germination and seedling growth. Biol. Plant., v. 50, n. 1, p. 156-158, 2006.

CABI. Invasive species compendium. Wallingford: CAB International, 2013. (www.cabi.org/isc).

CHUNG, I. M.; MILLER, D. A. Natural herbicide potential of alfalfa residues on selected weed species. Agron. J., v. 87, n. 5, p. 920-925, 1995.

GUPTA, S.; NARAYAN, R. Effects of applied leaf biomass of Parthenium hysterophorus, Cassia obtusifolia and Achyranthes aspera on seed germination and seedling growth of wheat and pea. Allelopathy J., v. 26, n. 2, p. 59-70, 2010.

HUSSAIN, F.; GADOON, M. A. Allelopathic effects of Sorghum vulgare Pers. Oecologia (Berl), v. 51, n. 2, p. 284-288, 1981.

JALAGERIA, B. R. et al. Allelopathic effects of prominent weed species on cereals, pulses and oil seed crops. Res. J. Agric. Sci., v. 1, n. 2, p. 107-112, 2010.

KIM, K. U.; SHIN, D. H. Rice allelopathy research in Korea. In: OLOFSDOTTER, M. (Ed.). WORKSHOP ON ALLELOPATHY IN RICE, 1996, Manila. Proceedings... Makati City: International Rice Research Institute, 1998. p. 39-44.

KOHLI, R. et al. Allelopathy and its implications in agro ecosystems. J. Crop Prod., v. 1, n. 1, p. 169-202, 1997.

ORCHARD, T. Estimating the parameters of plant seedling emergence. Seed Sci. Technol., v. 5, n. 1, p. 61-69, 1977.
OUDHIA, P.; TRIPATHI, R. S. Allelopathic effect of Lantana camera L. on rice. Agric. Sci. Digest (Karnal), v. 19, n. 1, p. 43-45, 1999.

RABBANI, N. et al. Interference of five problematic weed species with rice growth and yield. African J. Biotechnol., v. 10, n. 10, p. 1854-1862, 2011.

RAO, A. N. et al. Weed management in direct-seeded rice. Adv. Agron., v. 93, n. 1, p. 153-252, 2007.

SAMAD, M. A. et al. Allelopathic effects of five selected weed species on seed germination and seedling growth of corn. J. Soil. Nature, v. 2, n. 2, p. 13-18, 2008.

SETIA, N. et al. Phytotoxicity of volatile oil from Eucalyptus citriodora against some weedy species. J. Environ. Biol., v. 28, n. 1, p. 63-66, 2007.

SINGH, H. P. et al. Phytotoxic effects of Parthenium hysterophorus residues on three Brassica species. Weed Biol. Manag., v. 5, n. 3, p. 105-109, 2005.

STANP, N. Out of the quagmire of plant defense hypothesis. Quart. Rev. Biol., v. 78, n. 1, p. 23-55, 2003.

STEEL, R. G. D. et al. Principles and procedures of statistics. A biometrical approach. 3.ed. New York: McGraw Hill Book, 1996. 672 p.

TANVEER, A. et al. Allelopathic potential of Euphorbia helioscopia L. against wheat, chickpea and lentil. Turk J. Agric. For., v. 34, n. 1, p. 77-81, 2010.

TINNIN, R. O.; MULLER, C. H. The allelopathic influence of Avena fatua: the allelopathic mechanism. B. Torrey Bot. Club., v. 99, n. 6, p. 287-292, 1972.

ZIMDAHL, R. L. Fundamentals of weed science. 3.ed. London: Academic Press, 2007. 666 p. 